\title{
Regulation of the apoptotic response to radiation damage in B cell development
}

\author{
Kazuhiro Nishii ${ }^{1}$, Deena L. Gibbons ${ }^{1}$, lan Titley ${ }^{1}$, David \\ Papworth $^{2}$, Dudley T. Goodhead ${ }^{2}$ and Mel Greaves ${ }^{1,3}$ \\ ${ }^{1}$ Leukaemia Research Fund Centre at the Institute of Cancer Research, London \\ 2 Radiation and Genome Stability Unit, Medical Research Council, Harwell, \\ Didcot, Oxfordshire OX11 ORD, U.K. \\ ${ }^{3}$ corresponding author:Leukaemia Research Fund Centre, Institute of Cancer \\ Research, Chester Beatty Laboratories, 237 Fulham Road, London SW3 6JB, \\ U.K. tel: (+44 171) 352 8133; fax: (+44 171) 3523299 ; \\ e-mail: m.greaves@icr.ac.uk
}

Received 15.5.97; revised 30.7.97; accepted 7.8.97

Edited by M. Piacentini

\begin{abstract}
B lymphocyte precursor cells are ultrasensitive to DNA damage induced by irradiation and drugs and die by apoptosis at very low levels of exposure. Previous studies have shown that this high level sensitivity is p53-dependent, associated with very low level expression of $\mathrm{Bcl}-2$ protein and can be reversed by expression of a bcl-2 transgene. We show here that transition from the pro-B to pre-B and then mature $B$ cell stages of murine lymphopoiesis is accompanied by changes in proliferating cells in sensitivity to X-irradiation induced apoptosis and that this is paralleled by variation in the ratio of anti-(Bcl-2/Bcl- $\left.{ }_{\gamma \mathrm{L}}\right)$ to pro-(Bax) apoptotic proteins. These are however not fixed or invariant features of developmental stage as they can be modulated by interactions via adhesive interactions with stromal cells, stromal proteins and growth factors. We interpret these data in the context of the stringent developmental regulation of clonal lymphopoiesis and the contingency programming of cells that have extensive proliferative potential with a very low threshold for apoptosis following DNA damage.
\end{abstract}

Keywords: apoptosis; radiation; differentiation; lymphocytes; Bcl-2

Abbreviations: HA, hyaluronic acid; Gy, Grays

\section{Introduction}

Lymphocytes have been recognized for decades as radiationsensitive cells (Anderson and Warner, 1976; Trowell, 1952) and, recently, radiation-induced programmed cell death or apoptosis has endorsed this finding (Sellins and Cohen, 1987). Although apoptosis is probably a feature of all developmental pathways (Bowen and Lockshin, 1981; Raff, 1996; Williams et al, 1992) and many physiological responses, lymphocytes, along with a few other cell types (e.g., germ cells), appear to have a very low threshold for apoptosis which is linked to their radiation sensitivity. The functional or developmental logic behind this phenotype is likely to involve the unusual and stringent clonal selection events and cell loss via apoptosis which these cell populations undergo both in early differentiation and during immune responses (Osmond et al, 1994; Rolink and Melchers, 1991). Signals that induce apoptosis via genotoxic damage such as double-strand breaks in DNA usually require the presence of functional p53 protein which initiates cell cycle $\left(G_{1}\right)$ arrest and DNA repair or apoptosis (Donehower and Bradley, 1993; Kuerbitz et al, 1992). How a damaged cell elects to enter a DNA repair pathway or to apoptose is unclear but the process is regulated by the stoichiometry of complexes composed of $\mathrm{Bcl}-2$ and related proteins including $\mathrm{Bax}$ and $\mathrm{Bcl}_{\chi}$. Bcl-2 and $\mathrm{Bcl}_{\chi \mathrm{L}}$ (large variant) are antiapoptotic; Bax and $\mathrm{Bcl}_{-}{ }_{\mathrm{S}}$ (small variant) are pro-apoptotic (Boise et al, 1993; Nuñez et al, 1994; Sato et al, 1994; Yang and Korsmeyer, 1996). These proteins appear to regulate the activation of proteases involved in the apoptotic death mechanisms (Boise and Thompson, 1996; Nicholson et al, 1995). The vulnerability of lymphocytes and other cells to apoptotic signals can be dramatically altered by selective manipulation of the expression of these proteins, i.e., by transgenesis or transfection (Yang and Korsmeyer, 1996). These properties suggest that $\mathrm{Bcl}-2$ and related apoptosis modifying proteins will be subject to substantial regulation during development.

Lymphocytes are developmentally and functionally heterogeneous and sequential stages or subsets can be identified and manipulated in vitro (Ehlich et al, 1994; Faust et al, 1993; Hardy et al, 1991; Hayashi et al, 1990; Kee and Paige, 1995; Kincade, 1987). Lymphocyte subsets defined by developmental markers are not all equally sensitive to radiation or other apoptotic insults. We reported that murine IL7-dependent B lymphocyte precursors (pre-B cells) are ultrasensitive to plutonium-238 alpha particles such that they die following exposure to a single track of $\alpha$-particles (Griffiths et al, 1994b). The calculated $D_{0}$ value with X-rays for these cells ( $\sim 0.3 \mathrm{~Gy}$ ) was also substantially less than that of other haemopoietic precursor cells (myeloid) or mature B cells ( $\sim 1.2$ Gy) (Griffiths et al, 1994a). This suggests that at the mean lethal dose of X-rays for proliferating $\mathrm{B}$ cell precursors, around 10 double-stranded DNA breaks are sufficient to trigger apoptosis (c.f. Ward, 1988). This response is p53-dependent; $B$ cell precursors from p53 knockout mice are markedly radiation-resistant (Strasser et al, 1994; Griffiths et al, 1997). Pre-B cells express very low levels of $\mathrm{Bcl}-2$ protein and can be rendered considerably more resistant to irradiation (or etoposide/corticosteroid) induced cell death by expression of a bcl-2 transgene (Griffiths et al, 1994a; Strasser et al, 1994). Other data suggested that the immediate precursors of pre-cells, called pro-B cells, expressed higher levels of $\mathrm{Bcl}-2$ and were less sensitive to corticosteroid-induced apoptosis (Merino et al, 1994). However, the sensitivity of 
these very early $B$ lineage cells to genotoxic damage and apoptosis is unknown.

These data suggested that sensitivity to radiation is a component of apoptotic programming of lymphocytes, that this is developmentally regulated during lymphopoiesis and that the $\mathrm{Bcl}-2$ protein is able to modulate the sensitivity or threshold for apoptosis for p53-dependent (irradiation) or p53-independent (corticosteroid) apoptosis. Insight into the developmental regulation of responses to irradiation and other apoptotic signals has implications for the vulnerability of cells at different stages of differentiation to transformation via genotoxic damage and for the response of normal or malignant cells to genotoxic therapy. We have therefore sought to further define the developmental regulation of sensitivity to apoptosis induced by $\mathrm{X}$-irradiation in the $\mathrm{B}$ cell lineage. Specifically, experiments are designed to investigate how apoptosis induced by genotoxic damage varies during murine $B$ cell lymphopoiesis and whether this response shows a clear relationship with the relative levels or ratios of $\mathrm{Bcl}-2, \mathrm{Bax}$ and $\mathrm{Bcl}_{-}$proteins. Additionally, we have evaluated whether sensitivity at different stages of B cell differentiation can be modulated by adhesion or receptor signalling.

\section{Results}

B cell precursors belonging to sequential developmental stages, termed pro-B, pre-B1 and pre-B2, were cultured under selective conditions as described under Materials and Methods. Analysis of these populations with a panel of monoclonal antibodies and flow cytometry confirmed that they expressed the anticipated composite immunophenotypes appropriate for developmental stage. Representative flow cytometry profiles are given in Figure 1 and the overall data summarised in Table 1. We next compared the sensitivities of these three precursor populations, as well as mature B cells, to genotoxic damage (ionizing radiation and etoposide/VP-16) and corticosteroid (dexamethasone). Previous data had shown that pre-B2 cells were ultra-sensitive to these insults and underwent apoptosis at very low levels of exposure (Griffiths et al, 1994a). This was confirmed in the present experiments as shown in Figure 2 in which two outcomes of exposure were evaluated-apoptosis (measured by flow cytometry) and loss of clonogenicity. These comparative tests show that stroma-associated pro-B and pre-B1 cells are less sensitive to apoptosis induced by all three insults than pre-B2 cells. The analysis of X-ray survival data for this and subsequent experiments is summarized in Table 2 . In clonogenic assays, the rank order of increasing sensitivity to all three insults was pre-B2 $>$ pre-B1 $>$ pro-B $>$ mature $\mathrm{B}$ (spleen).

The sensitivity of pre-B2 cells to genotoxic damage and corticosteroid-induced apoptosis is known to be associated with low level expression of the anti-apoptotic protein Bcl-2 (Griffiths et al, 1994a). It is now recognised that Bcl-2 protein is not itself an exclusive regulator of apoptosis but operates in concert with related members of a family of proteins; these exert pro- or anti-apoptotic functions, the outcome most probably depending upon the stoichiometry of complexes involving these different proteins. Key players
$B 220$

\section{Pro-B}

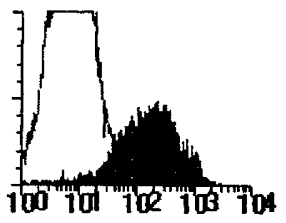

Pre-B1
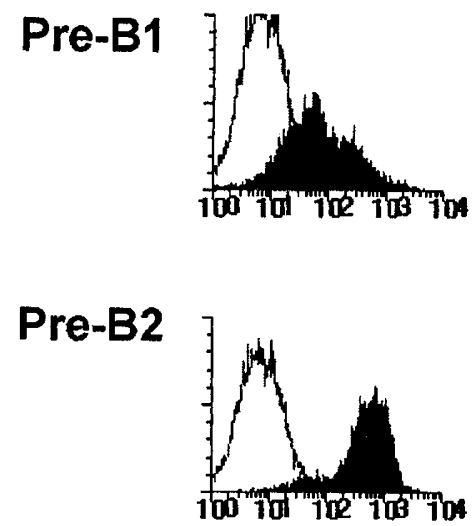

$B P-1$
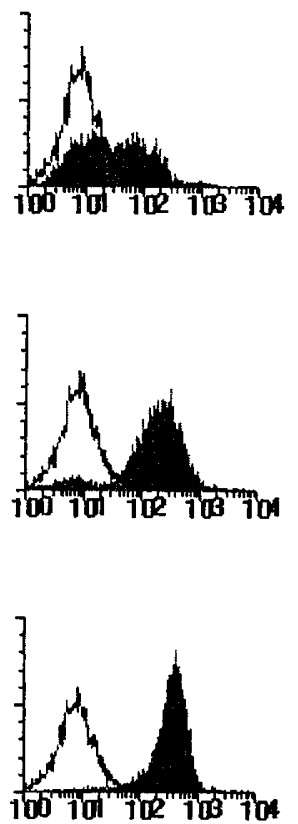

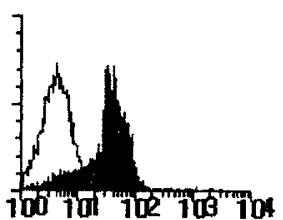

c-kit
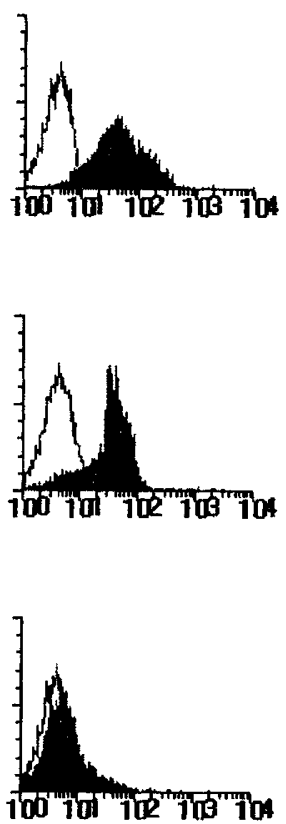

Thy-1
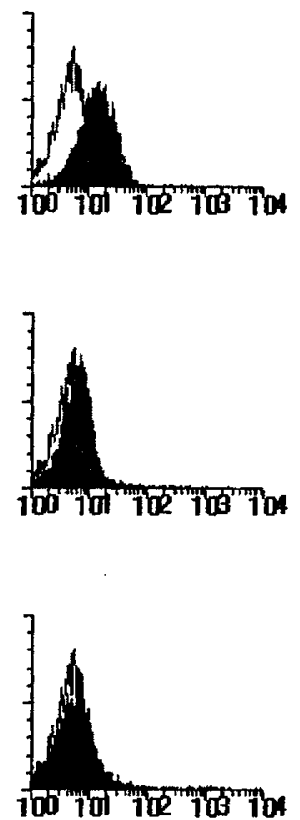

Figure 1 Distinctive immunophenotypes of sequential B cell precursors. Flow cytometry (log plot) profiles of pro-B, pre-B1 and pre-B2 cells stained with four antibodies detecting the cell surface markers-B220, BP1, c-kit, thy-1. Solid curve, antibody reactivity; open curve, control Ig 
Table 1 Immunophenotypes of B lineage subsets identified in this study

\begin{tabular}{|c|c|c|c|c|c|c|c|c|c|c|c|}
\hline & B220 & HSA & CD43 & CD44 & BP1 & kit & $\begin{array}{l}\text { CD25 } \\
\text { (IL2 } R \text { ) }\end{array}$ & CD19 & Thy1 & $\mu$ cyto & Smig \\
\hline 1. Pro-B & + & + & + & + & s+ & ++ & - & + & + & - & - \\
\hline 2. Pre-B1 & + & ++ & + & + & ++ & + & - & + & - & - & - \\
\hline 3. Pre-B2 & ++ & ++ & + & + & ++ & - & $s+$ & + & - & $\mathrm{s+}$ & - \\
\hline 4. B (spleen) & ++ & $\mathrm{NT}(-)$ & $\mathrm{NT}(-/+)$ & $\mathrm{NT}(+)$ & - & - & - & + & - & - & + \\
\hline
\end{tabular}

Reactivity of cells to monoclonal antibodies determined by flow cytometry (see Figure 1 for examples). $\mu$ cyto, cytoplasmic staining for $\mu$ heavy chain. Smlg, cell surface membrane associated immunoglobulin. - , less than $5 \%$ cells reactive with corresponding antibody.,$+>50 \%$ cells reactive.,$++>90 \%$ strongly reactive. S+, subset of cells $(5-30 \%)$ reactive with antibody. NT, not tested in this study but reported (for mature B cells) in other studies. $(-/+)-$ for CD43/mature $B /$ spleen cells $=$ resting cells unreactive but expression induced by activation (e.g. by LPS)

in this respect are $\mathrm{Bcl}-2$ (anti-apoptotic), Bcl- ${ }_{\mathrm{L}}$ (antiapoptotic), Bcl- $\chi \mathrm{S}$ (pro-apoptotic) and Bax (pro-apoptotic). Pro-B, pre-B1, pre-B2 and mature B cells were therefore analyzed for expression of these proteins using two immunological approaches. First, by flow cytometry using the corresponding antibodies. This test revealed a variable level of expression between the cell types (Figure 3). When the arbitrary values for mean levels of expression determined by intensity of fluorescence in flow cytometry (Figure 4A) were converted into a ratio of anti- to proapoptotic proteins, there is a striking difference in the cell types that is reciprocal in rank order to their sensitivity to apoptosis, i.e., pre-B2 cells have the lowest 'protective' ratio, mature (splenic) B cells have the highest, the overall difference being around tenfold (Figure 4B). We confirmed this variation in protein expression by Western blot using the same antibodies (Figure 4C). Although not quantified, the relative levels of $\mathrm{Bcl}-2$ and $\mathrm{Bcl}_{-}$, were as anticipated from the flow cytometry data. Note also that the Western blot data indicated that $\mathrm{Bcl}_{\chi}$ was exclusively the large or anti-apoptotic variant (Boise et al, 1993).

These data suggest that there is a developmental programming of apoptosis sensitivity in B cell lymphopoiesis, that this is set at maximum sensitivity at the pre-B2 stage of differentiation when $\mathrm{IgH}$ gene rearrangement occurs (Hardy et al, 1991; Kee and Paige, 1995) and that a critical determinant of relative sensitivity is the variable ratio of pro- to anti-apoptotic proteins of the Bcl-2 family. These data do not reveal, however, whether the developmental differences observed are invariant and intrinsic to the sequential stage of differentiation of the cell or whether they are, at each stage, modulated by signals received from other cells. The superior survival of pro-B and pre-B1 over pre-B2 cells might, for example, be a reflection of signals received via stromal cell contacts that upregulate $\mathrm{Bcl}-2 / \mathrm{Bcl}-{ }_{\gamma \mathrm{L}}$ expression.

To evaluate this possibility, we tested whether providing pre-B2 cells with adhesive contacts decreased sensitivity to irradiation concomitant with modulation of $\mathrm{Bcl}-2+\mathrm{Bcl}_{-}{ }_{\chi}$ over Bax ratios. First, in order to test whether cellular adhesion itself in the absence of associated growth factors would decrease sensitivity of pre-B2 cells to apoptosis, we cultured these cells with matrigel-a composite of stromal matrix proteins including fibronectin and collagen. In some experiments we also added an additional matrix proteoglycan to the matrigel-hyaluronic acid $(H A)$. The rationale here was that $B$ cells have been shown previously to adhere to HA in stromal matrices via their cell surface CD44 (Miyake et al, 1990). We confirmed that our pre-B2 cells all expressed the CD44 molecule including the epitope that appears to be topologically linked to HA binding (Lesley et al, 1992) (Figure 5A). Brief (1-3 day) exposure of pre-B2 cells to matrigel with or without HA had no impact on their sensitivity to $\mathrm{X}$-irradiation (data not shown). After 5 days, there was a small decrease in radiation sensitivity in cells that had adhered to matrigel (Figure 5B) but this rescue was more pronounced on matrigel plus $\mathrm{HA}$ and even more so when pre-B2 were allowed to remain in contact with matrigel plus $\mathrm{HA}$ during irradiation and for $2 \mathrm{~h}$ thereafter before plating in agar for clonogenic survival (Figure 5B, Table 2). The decrease in sensitivity to $X$ irradiation provided by sustained adherence to matrigel plus $\mathrm{HA}$ was accompanied by upregulation of $\mathrm{Bcl}-2$ and $\mathrm{Bcl}_{\gamma \mathrm{L}}$ proteins and an overall increase in the $\mathrm{Bcl}-2$ plus $\mathrm{Bcl}^{-} \mathrm{L}$ to Bax ratio (Figure $5 \mathrm{C}$ ).

We next investigated whether IL7-dependent pre-B2 cells had an improved resistance to $\mathrm{X}$-irradiation if allowed to make contact with viable bone marrow stromal cells which might provide not only adhesive contact sites but growth factors. The results (Figure $6 \mathrm{~A}$ ) indicate that pre-B2 cells in contact with stroma are still very radio-sensitive but less so than in the absence of stroma. The sensitivity of stroma-associated pre-B2 cells, as with matrigel plus HA associated pre-B2 cells, approaches that of their precursor pre-B1 cells (Figure 6A, Table 2). Since this albeit modest increase in resistance appeared to be conferred rapidly by stroma, i.e., after $2 \mathrm{~h}$ of contact compared with the several days required for matrigel plus $\mathrm{HA}$, we assayed levels of $\mathrm{Bcl}-2, \mathrm{Bcl}_{\gamma \mathrm{L}}$ and Bax by flow cytometry and Western blotting. Binding to stroma induced a more than threefold increase in expression of $\mathrm{BCl}-2$ and a doubling of $\mathrm{BCl}_{\chi} \mathrm{L}$ levels. Bax levels were very marginally increased also (Figure 6B). Overall this provided a 2-3-fold increase in the $\mathrm{Bcl}-2$ plus $\mathrm{Bcl}_{-} \mathrm{L}$ to Bax ratios (Figure $6 \mathrm{~B}$ ). This result was confirmed by Western blotting (Figure $6 \mathrm{C}$ ). Following radiation (1 Gy) of pre-B2 cells, with or without stromal support, Bcl-2 levels declined, whereas $\mathrm{Bcl}_{\chi \mathrm{L}}$ and $\mathrm{Bax}$ increased as previously reported (Kitada et al, 1996; Miyashita et al, 1994). Post-radiation, Bcl-2 plus $\mathrm{Bcl}_{\chi}{ }_{\chi \mathrm{L}}$ over Bax ratios remained higher in pre-B2 cells in contact with stroma (Figure 6B). 
We conclude from these experiments that although $B$ cell precursors appear to be intrinsically very sensitive to $X$ irradiation-induced apoptosis that this can be subject to modulation by stromal cell or stromal matrix contact and that, as with sequential stages of early B cell differentiation, variable sensitivity is closely associated with the ratio of anti- to pro-apoptosis regulating proteins, $\mathrm{Bcl}-2, \mathrm{Bcl}_{\chi_{\mathrm{L}} \mathrm{L}}$ and Bax.

\section{Apoptosis (\%)}
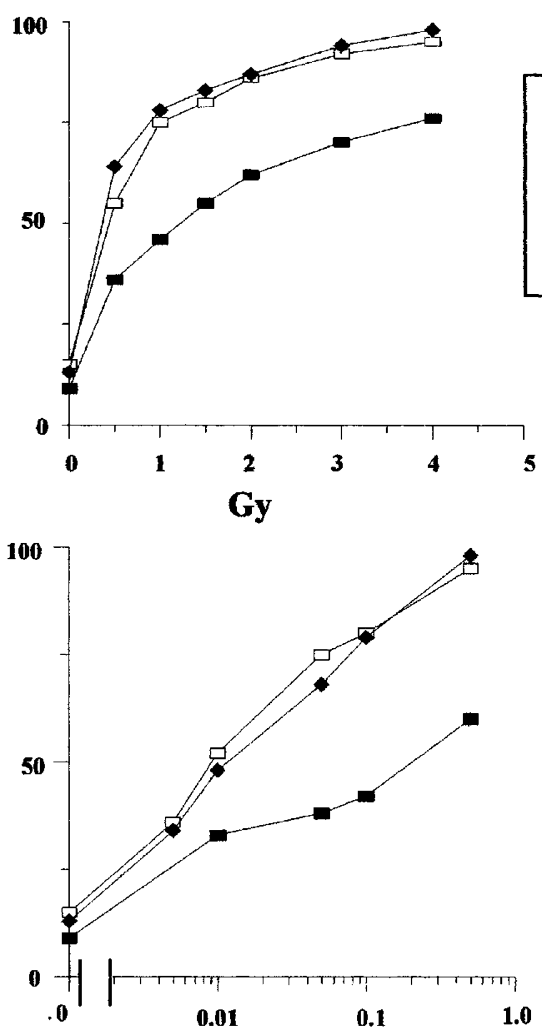

$\operatorname{Dex}(\mu \mathrm{M})$

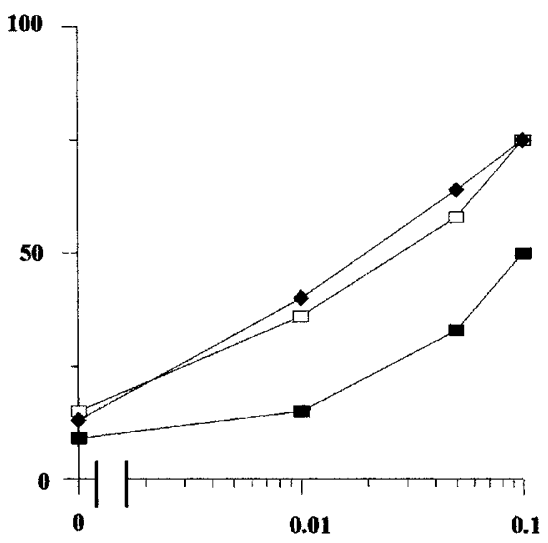

VP-16 ( $\mu \mathrm{g} / \mathrm{ml})$

\section{Clonogenic survival (\%)}
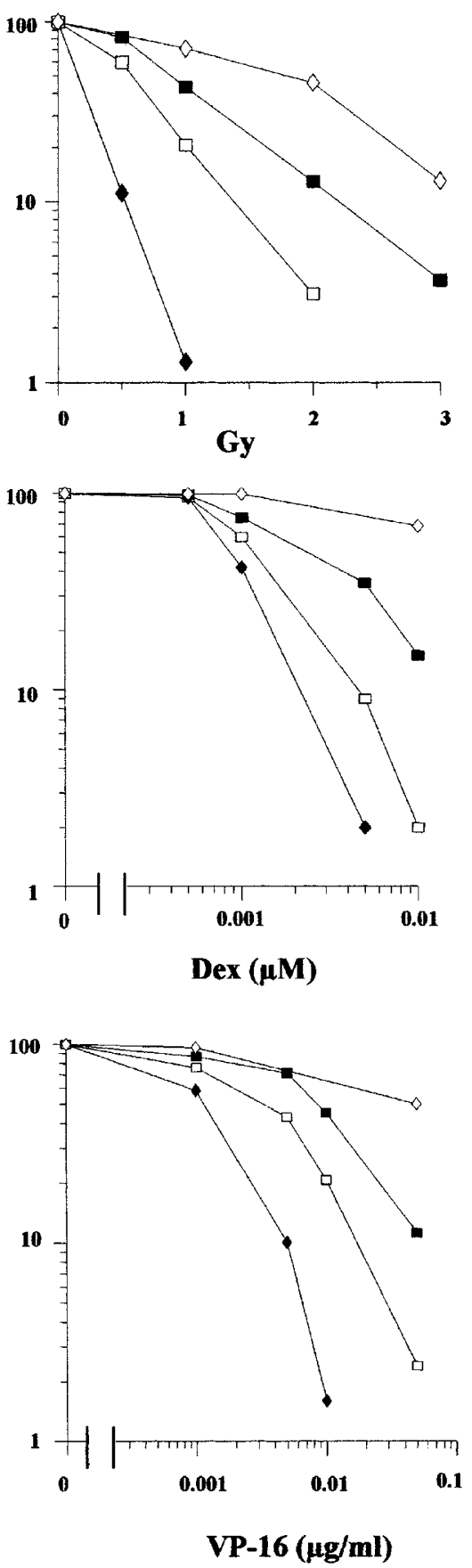

Figure 2 Developmental sensitivity of B cell lineage cells to apoptotic signals: measurement of apoptosis and loss of clonogenicity. Cells were exposed to xirradiation (0.5-4 Gy), or continuously in culture to dexamethasone (Dex) or etoposide (VP-16). Apoptosis was measured by DNA staining and flow cytometry after $24 \mathrm{~h}$ and clonogenic survival after 7 days (see Methods). Values given/vertical axis represent percentage of cells in the sub $\mathrm{G}_{1}$ peak of DNA staining. One representative experiment of three giving similar results is shown. Error bars derived from replicate exposures in this experiment are not shown but standard errors were calculated for each point and used in the calculation of $D_{37}$ values (Table 2) 
Table 2 Analysis of X-ray clonogenic survival data

\begin{tabular}{|c|c|c|c|c|}
\hline $\begin{array}{l}\text { Exp/ } \\
\text { Figure. }\end{array}$ & Cells & $\begin{array}{c}\alpha \\
\left(G y^{-1}\right)\end{array}$ & $\begin{array}{c}\beta \\
\left(\mathbf{G y}^{-2}\right)\end{array}$ & $\begin{array}{l}D_{37} \\
\text { (Gy) }\end{array}$ \\
\hline \multirow[t]{2}{*}{ Figure 2.} & $\begin{array}{c}\text { Pro-B } \\
\text { Pre-B1 } \\
\text { Pre-B2 } \\
\text { Spleen B }\end{array}$ & $\begin{array}{l}0.99 \pm 0.23 \\
1.57 \pm 0.25 \\
4.36 \pm 0.28 \\
0.00 \pm 0.18\end{array}$ & $\begin{array}{c}- \\
- \\
- \\
0.22 \pm 0.07\end{array}$ & $\begin{array}{l}1.01 \pm 0.23 \\
0.64 \pm 0.10 \\
0.23 \pm 0.02 \\
2.13 \pm 0.31\end{array}$ \\
\hline & \multicolumn{4}{|c|}{ Pre-B2 $>$ Pre-B1 $>$ Pro-B $>$ Mature B. $P<10^{-5}$} \\
\hline \multirow[t]{2}{*}{ Figure 5.} & $\begin{array}{l}\text { Pre-B2 } \\
\text { (stroma) }\end{array}$ & $2.08 \pm 0.21$ & - & $0.48 \pm 0.05$ \\
\hline & \multicolumn{4}{|c|}{ Pre-B2 $>$ Pre-B2/Stroma $>$ Pre-B1. $P<5 \times 10^{-4}$} \\
\hline \multirow[t]{3}{*}{ Figure 4.} & $\begin{array}{c}\text { Pre-B2 } \\
\text { Pre-B2+ } \\
\text { MT/HA }(0 \mathrm{~h})\end{array}$ & $\begin{array}{l}4.18 \pm 0.45 \\
2.67 \pm 0.41\end{array}$ & - & $\begin{array}{l}0.24 \pm 0.03 \\
0.38 \pm 0.06\end{array}$ \\
\hline & $\begin{array}{l}\text { Pre-B2+ } \\
\text { MT/HA (5 h) }\end{array}$ & $0.58 \pm 0.53$ & $1.19 \pm 0.55$ & $0.71 \pm 0.12$ \\
\hline & \multicolumn{4}{|c|}{$\begin{array}{c}\text { Pre-B2 }>\text { Pre-B2 MT/HA }(0 \mathrm{~h})>\text { Pre-B2 } \\
\text { MT/HA }(5 \mathrm{~h}) . P<5 \times 10^{-3}\end{array}$} \\
\hline
\end{tabular}

This table shows coefficients of fit to linear exponential survival curves $(S=e x p-$ $\alpha D$ ), except for data sets that show a significant curvature as indicated by a $\beta$ coefficient whose standard deviation does not overlap zero when the data are fitted to a linear quadratic exponential survival curve $\left(S-\operatorname{ext}-\left(\alpha D+\beta D^{2}\right)\right)$. The $D_{37}$ doses have been evaluated from these fits as the dose giving a surviving fraction of $37 \%$

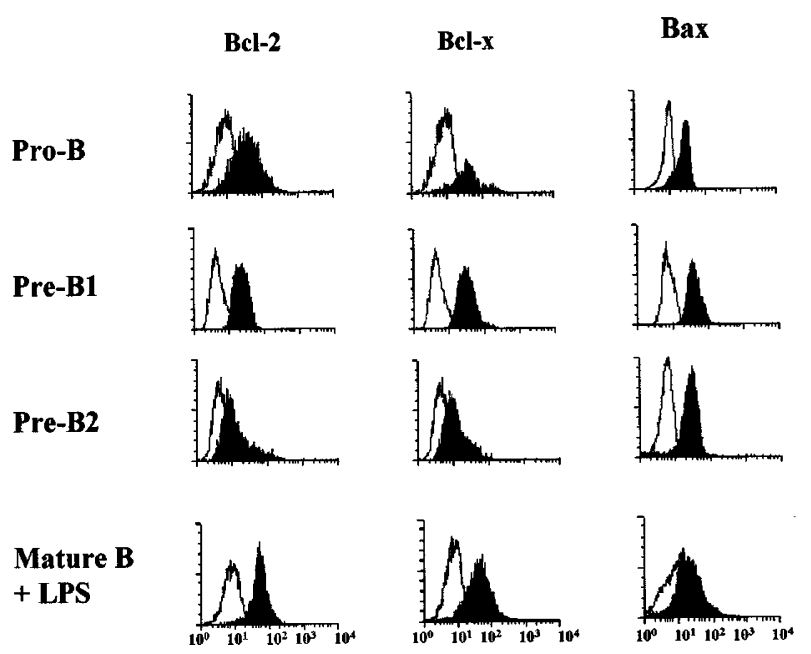

Figure 3 Flow cytometric analysis of $\mathrm{Bcl}-2, \mathrm{Bcl}_{\chi}$ and $\mathrm{Bax}$ cytoplasmic proteins in $B$ lineage cells at sequential stages of differentiation. FACScan profile: vertical (linear) axis-relative cell number; horizontal (log) axisrelative fluorescence intensity. Solid distribution-specific antibody; open distribution-control (isotype matched) immunoglobulin

\section{Discussion}

These data show that the sensitivity or threshold setting for the $\mathrm{X}$-irradiation-induced apoptotic response during $\mathrm{B}$ cell lymphopoiesis varies between pro-B, pre-B1, pre-B2 and $\mathrm{B}$ cells and that there is a correlation between this sensitivity profile to three apoptotic stimuli (X-irradiation, etoposide and corticosteroid) with the relative ratios of pro- and anti- apoptotic regulatory proteins of the Bcl-2 family, i.e., Bax versus $\mathrm{Bcl}-2$ and $\mathrm{Bcl}_{\gamma \mathrm{L}}$. Other data have suggested that in different cellular systems, the stoichiometry of $\mathrm{Bcl}-2$ complexed with related proteins may critically influence whether cells die or are reprieved from a variety of apoptotic insults (reviewed in Yang and Korsmeyer, 1996). As reported by others also (Grillot et al, 1995; Ma et al, 1995), lymphocyte precursors express, predominantly, the large splice variant of $\mathrm{BCl}{ }_{\mathrm{L}}$ which, like $\mathrm{Bcl}-2$, is anti-apoptotic rather than the smaller variant which is pro-apoptotic. All stages of B cell lymphopoiesis co-expressed $\mathrm{Bcl}-2$, Bax and $\mathrm{Bcl}_{-2 \mathrm{~L}}$ but it was the variation in the levels of the anti-apoptosis proteins $\mathrm{Bcl}-2$ and $\mathrm{Bcl}_{\chi \mathrm{L}}$ that contributed most significantly to the differences in apoptosis sensitivity. For example, pro-B cells have higher $\mathrm{Bcl}-2 / \mathrm{Bax}$ and $\mathrm{Bcl}_{-{ }_{\mathrm{L}}} / \mathrm{Bax}$ ratios than pre-B cells. A similar sequence of events linking expression of these proteins with sensitivity to apoptosis probably occur during early $\mathrm{T}$ cell development within the thymus. Early $\mathrm{T}$ cell precursors $\left(\mathrm{CD} 4^{-} / \mathrm{CD}^{-}{ }^{-}\right.$) equivalent to pro-B cells express $\mathrm{Bcl}-2$ but this is down-regulated as they enter the $\mathrm{CD} 4^{+} / \mathrm{CD} 8^{+}$stage of $\mathrm{T}$ cell receptor rearrangement and undergo clonal deletion by apoptosis (Gratiot-Deans et al, 1994; Veis et al, 1993). A possible difference however appears to be that whereas we find both $\mathrm{Bcl}-2$ and $\mathrm{Bcl}-{ }_{\gamma \mathrm{L}}$ are down-regulated in pre-B cells, it has been reported that equivalent pre-T, $\mathrm{CD} 4^{+} / \mathrm{CD} 8^{+}$ thymocytes down-regulate $\mathrm{Bcl}-2$ but not $\mathrm{Bcl}_{\gamma \mathrm{L}}$ (Grillot et al, 1995; Ma et al, 1995). Other data also shows that Bcl-2 and $\mathrm{BCl}_{\chi}{ }_{\mathrm{L}}$ can be reciprocally regulated and have overlapping or redundant function (Grillot et al, 1996; Mueller et al, 1996). Mature resting (out of cycle) splenic B cells have a high $\mathrm{Bcl}-2$ / $B a x$ ratio but low level $\mathrm{Bcl}_{\chi \mathrm{L}}$ expression. When activated into cycle by LPS, Bcl- ${ }_{\mathrm{L}}$ selectively increases (Grillot et al, 1996) in accord with our data (Figure 3 ) showing relatively high levels of $\mathrm{Bcl}_{\gamma}$, protein in mature B cells stimulated by LPS. These data indicate that cell cycle or activation status is a significant regulator of apoptosis sensitivity independent of differentiation stage. Other recent studies also provide evidence of cross-talk or co-regulation of cell cycle progression and cell death involving $\mathrm{Bcl}-2$ (Mazel et al, 1996; O'Reilly et al, 1996; Linette et al, 1996). Although not investigated in our study, it is likely that the interaction of Bcl-2 with its partner proteins and its functional activity can also be regulated by phosphorylation (Haldar et al, 1995). Recent studies also indicate that in addition to $\mathrm{Bcl}-2, \mathrm{Bcl}_{-}$, and $\mathrm{Bax}$, several other related proteins including Bad, Bak and others may regulate apoptosis (Gajewski and Thompson, 1996; Vaux and Strasser, 1996). Differential expression of these proteins in B cell development might also be relevant to the variable sensitivity to apoptosis that we observe. This has not been assessed but any variability might be expected, from our results, to be co-ordinate with $\mathrm{Bcl}-2 / \mathrm{Bcl}_{-}$to Bax ratios.

Developmental regulation in vivo involves not only growth factor receptor stimulation but adhesive interactions with tissue stromal cells and stroma-associated matrix proteins. In haemopoietic and other systems, such stromal matrices may present bound growth factors (Gordon et al, 1987) and rescue cells from apoptosis (Manabe et al, 1992; Ruoslahti and Reed, 1994). Extracellular matrix protects endothelial cells from radiation injury (Fuks et al, 1992). We show here that the extreme vulnerability of pre-B cells to 

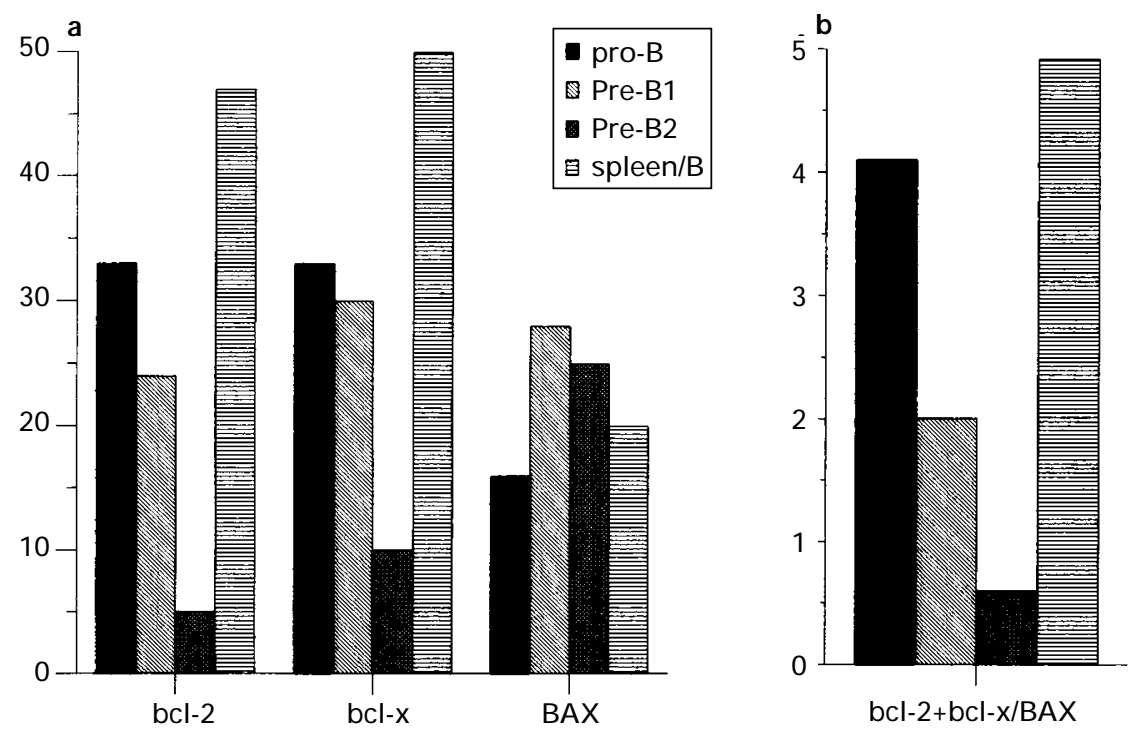

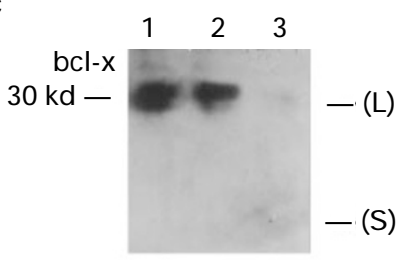

bcl-2

$30 \mathrm{kd}-$

Figure 4 Developmental changes in the relative levels of $\mathrm{Bcl}-2, \mathrm{Bcl}^{-}{ }_{\mathrm{L}}$ and $\mathrm{Bax}$ proteins. A/B:relative levels of proteins determined by flow cytometry with appropriate antibodies. (A) Vertical axis = median fluorescence channel numbers (above control), i.e., antibody staining intensity. We also compared protein levels by taking the ratio of median staining with antibody over that of the control. This gave similar data to that illustrated above. (B) Ratio of mean fluorescence channel numbers for Bcl-2 plus Bcl- ${ }_{\chi}$ over Bax. (C) Relative levels of $\mathrm{Bcl}-2$ and $\mathrm{Bcl}_{\chi} \mathrm{L}$ proteins determined by Western blotting with appropriate antibodies $(\mathrm{L})=$ large variant of $\mathrm{Bcl}_{\chi} ;(\mathrm{S})$ - small variant of $\mathrm{Bcl}_{\chi} .1=$ pro-B cells. $2=$ pre-B1 cells. $3=$ pre-B2 cells. The results of one experiment are shown. In three repeat experiments, essentially the same results were obtained

apoptosis can also be decreased, though not reversed, in vitro by adhesive interactions that mimic those observed in vivo (Osmond et al, 1994). Thus pre-B2 cells bound to matrigel plus hyaluronic acid selectively upregulate Bcl-2 and $\mathrm{Bcl}_{\chi \mathrm{L}}$ and become less radiation-sensitive, approximating to that of bone marrow stroma-associated pre-B1 cells. Matrix-associated hyaluronic acid is recognised by lymphoid cell surface CD44 as an adhesion ligand and inhibition of this interaction blocks B cell lymphopoiesis (Miyake et al, 1990). Conversely, pro-B cells down-regulate $\mathrm{Bcl}-2$ (and upregulate Bax) when removed from stromal cultures (Gibson et al, 1996). The former result suggests that adhesion itself can generate a signal upregulating Bcl2 and $\mathrm{BCl}_{\chi \mathrm{L}}$. Modulation on matrigel-HA takes several days but a similar shift of sensitivity to radiation and in Bcl$2+\mathrm{Bcl}_{\gamma \mathrm{L}}$ to Bax ratio can be induced within $2 \mathrm{~h}$ by plating IL7-dependent pre-B cells on viable stromal cells. Note however that in more general terms, stroma-dependent pro$B$ and pre-B cells bound to matrigel are still radiationsensitive cells. The modest protection afforded by hyaluronic acid bound to matrigel or viable stromal cells cannot be substituted by stromal cell supernatants or IL3 ( $\mathrm{KN}$, unpublished results). We assume therefore that stromal adhesive contacts and stroma derived and bound growth factors may be important. Other data suggest that stroma-associated growth factors including kit ligand (stem cell factor) are probably important regulators of B cell precursor survival (Billips et al, 1992; Rolink et al, 1991).

This response of $B$ cell precursors (and $T$ ) to radiation is p53-dependent (Strasser et al, 1994; Griffiths et al, 1997) and is mirrored by sensitivity to genotoxic drugs such as etoposide. There is evidence that these cells do not incur more DNA strand breaks per Gy of irradiation than other cell types and that they are capable of at least gross double-strand break repair as indicated in the comet DNA electrophoresis assay (Griffiths et al, 1997). These cells are also exquisitely sensitive to a p53-independent apoptosis pathway induced by corticosteroid. The unusual feature of these cells is therefore their predisposition to follow the apoptosis response rather than sensitivity for induction of initial molecular damage by ionizing radiation.

Although the level of sensitivity varies, it is maximal at the pre-B stage of development when these cells are undergoing immunoglobulin gene rearrangement. There are sound developmental reasons why such a contingency plan should be developmentally programmed into lymphopoiesis. First, that clones of $\mathrm{B}$ (and $\mathrm{T}$ ) cell precursors with either aberrantly rearranged (e.g., out of frame) or high affinity self-reactive immunoglobulin (or $\mathrm{T}$ cell) receptors need to be eliminated. Second, that the dynamics of lymphopoiesis and clonal selection also operates in large measure by the provision or denial of a reprieve from cell death, i.e., precursor cells are programmed with a major default pathway of apoptosis and can only survive and differentiate further if rescued with an appropriate physiological signal which is contingent upon a functional $\mathrm{IgH}$ gene rearrangement (Rolink and Melchers, 1991). In vivo analysis and kinetic studies testify to the substantial cell loss by apoptosis in normal B cell lymphopoiesis in vivo (Osmond et al, 1994). Passage through this developmental graveyard is associated with upregulation of $\mathrm{Bcl}-2$ levels following successful $\mathrm{lgH}$ gene rearrangement and is greatly 
reduced in mice rendered homozygous null for Bcl-2 (Cory, 1995; Matsuzaki et al, 1997). In these respects, lymphocyte precursors are not however unique. The germinal centre stage of mature $\mathrm{B}$ cell expansion and $\lg \mathrm{H}$ gene hypermutation during the immune response is another developmental stage of apoptotic sensitivity and stringent clonal selection. This is also tightly associated with regulation of $\mathrm{Bcl}-2$ (Liu et al, 1991).

a

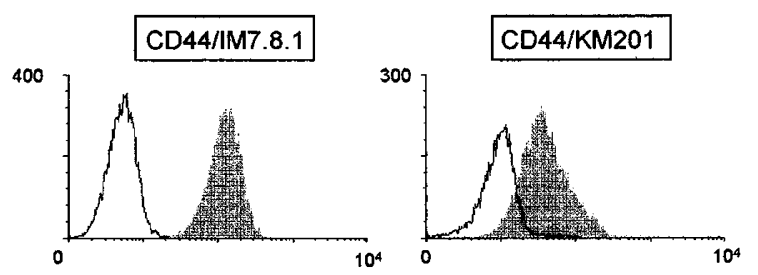

b

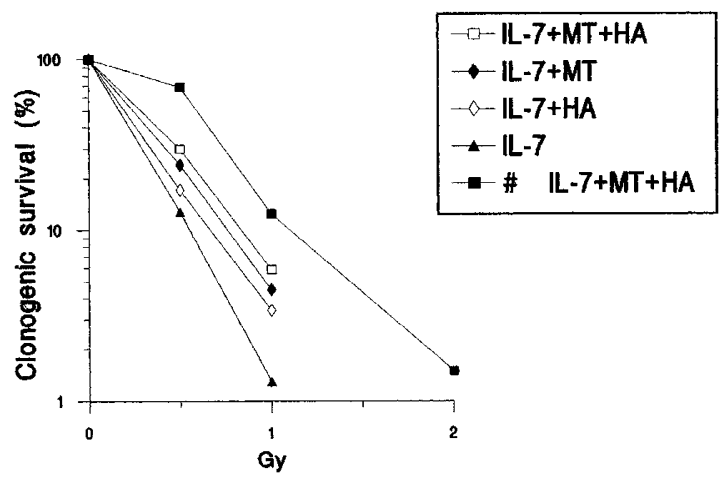

C

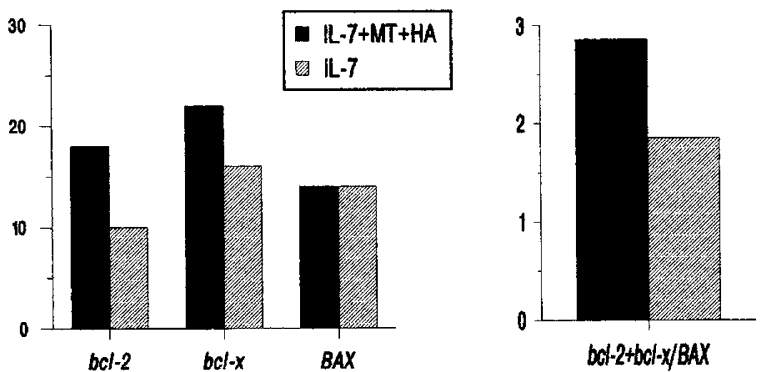

Figure 5 Adhesion to matrigel plus hyaluronic acid increases resistance of pre-B2 cells to $\mathrm{X}$-irradiation and modulates $\mathrm{Bcl}-2 / \mathrm{Bcl}-{ }_{2 \mathrm{~L}}$ levels. (A) Pre-B2 cells express CD44, the 'receptor' for matrix associated hyaluronic acid. Antibody binding evaluated by flow cytometry. Monoclonal antibody specific for CD44-IM7. Monoclonal antibody KM201 binds to a CD44 epitope close to the hyaluronic acid recognition site (Lesley et al, 1992). Vertical axis = number of cells; horizontal axis = fluorescence intensity. Shaded profile=CD44 antibody, open profile $=$ control, Ig class matched. (B) Pre-B2 cells were cultured on matrigel (MA) with or without hyaluronic acid $(\mathrm{HA})$ for 5 days and removed from the matrigel, $\mathrm{X}$-irradiated and immediately plated in agar with IL7 for clonogenicity evaluation. In samples labelled \# cells were irradiated whilst still attached to matrigel plus $\mathrm{HA}$ and were plated for clonogenic assay after a further $2 \mathrm{~h}$. (C) Relative levels of $\mathrm{Bcl}-2, \mathrm{Bcl}{ }_{\mathrm{L}}$ and Bax proteins as determined by flow cytometry. Left side: vertical axis, antibody reactivity by flow cytometry, median fluorescence channel numbers, i.e., average cellular intensity of staining. Right side: ratio of Bcl-2 plus Bcl- ${ }_{\chi \mathrm{L}}$ over Bax. Data from one of three experiments is shown
In a more general biological sense, precursor cells are produced in excess in many, if not most, lineages during development, e.g., oligodendrocytes (Barres et al, 1992) and the majority are lost, probably by apoptosis default, in the absence of rescue by the appropriate developmental cue or cellular partnership (Ellis et al, 1991; Raff, 1996). However, in these situations radiation sensitivity has not, as far as we know, been systematically analyzed; it could be similar to that of lymphocyte precursors.

There is an additional reason why $B$ and $T$ cell precursors and certain other cells should be programmed with a high sensitivity for apoptosis. Lymphocytes are very unusual in being long lived with extensive self-renewal or proliferative capacity. They are therefore doubly vulnerable to malignant transformation that might follow from exposure to genotoxic damage-during the $\operatorname{lgH}$ gene recombination process which involves DNA double stranded break repair and, as mature proliferating cells. Such vulnerability requires protection to minimise risk and this is provided by a dominance of p53-induced apoptosis over attempted repair, i.e., the prudent rule is - if damaged, then die. Few other cell types in the adult body incur similar life time risks. Germ cells are similar in that they undergo DNA recombination processes and generate a potentially immortal proliferative lineage. Interestingly at a post-spermatogonial or transit stage that might be considered developmentally similar to pre-B cells, germ cells express p53, have a high rate of spontaneous apoptosis (Blanco-Rodríguez and Martínez-García, 1996) and are extremely sensitive to irradiation-induced cell death (Judas et al, 1996). Early embryo cells are also 'at risk' in these respects as sustained or unrepaired genetic damage might result in mutant offspring. It is interesting therefore that, as with lymphocyte precursors, expression or rapid induction of p53 following irradiation is associated with apoptosis and foetal loss (Komarova et al, 1997; Norimura et al, 1996). These three situations, lymphopoiesis, spermatogenesis and early embryo cells, therefore share a developmental propensity to p53dependent apoptosis as altruistic suicide. It is likely that efficient execution of the cell death pathway in all of these situations is contingent upon low level $\mathrm{Bcl}-2 / \mathrm{Bcl}-{ }_{\gamma}$ over $\mathrm{Bax}$ ratios as shown here for $B$ cell lymphopoiesis.

Despite being equipped with suicidal protection against genotoxic damage that might otherwise lead to malignant transformation, lymphocyte precursors and germ cells can become leukemic (acute lymphoblastic) or cancerous (testicular carcinoma). Transformation is associated with acquired chromosome alterations that must include DNA breaks (Rabbitts, 1994) but might be expected from our data to occur in the absence of gross genotoxic damage. Irrespective of the aetiological mechanism involved, it is striking that acute lymphoblastic leukemia and testicular cancer, even when widely disseminated, are often very sensitive to genotoxic therapy (irradiation and chemotherapy) and curable. We have speculated that this clinical success is contingent upon the intrinsic programming of these cell types with a high sensitivity for apoptosis (Greaves, 1993). Interestingly, the striking exception to this-Philadelphia chromosome positive acute lymphoblas- 

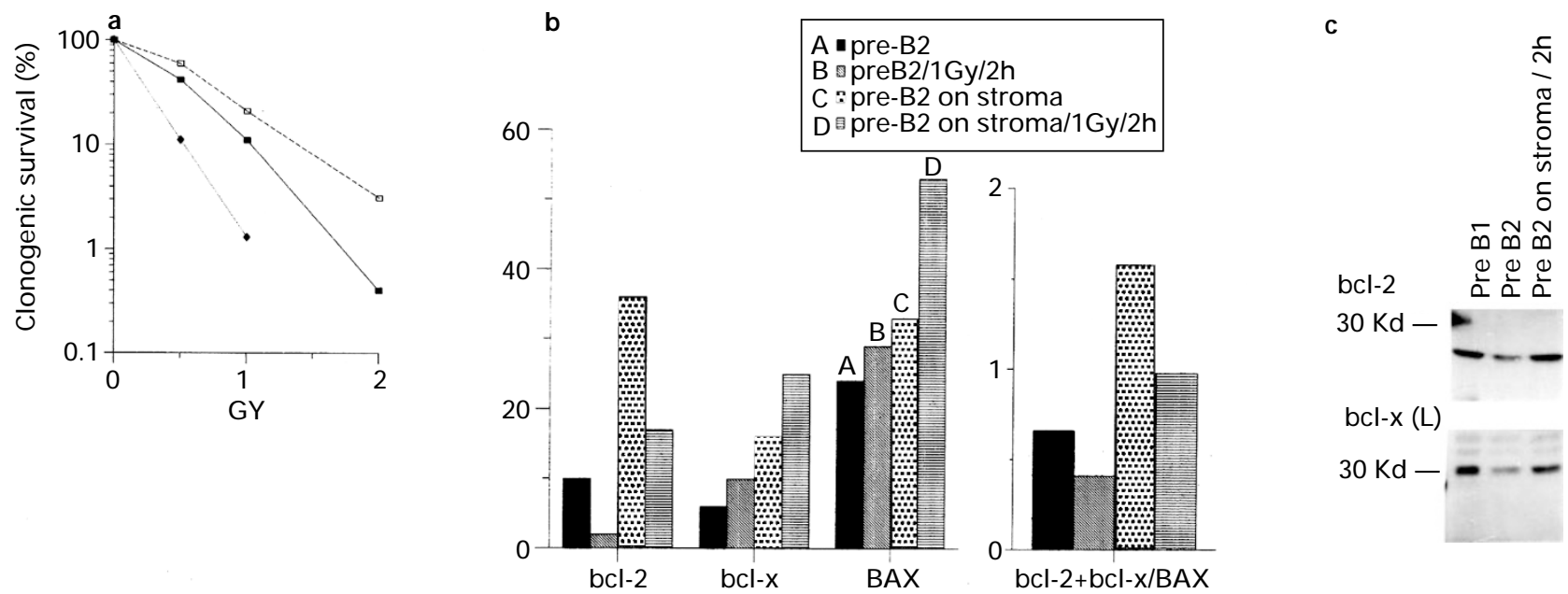

Figure 6 Binding of pre-B2 cells to bone marrow stromal cells for $2 \mathrm{~h}$ increases resistance to ionizing radiation and upregulates $\mathrm{Bcl}-2$ and $\mathrm{Bcl}-{ }_{\chi \mathrm{L}}$. (A) Survival of clonogenic pre-B2 cells with and without stroma after irradiation in the absence of stroma. (B) Relative levels of $\mathrm{Bcl}-2$, Bcl- ${ }_{\gamma} \mathrm{L}$ and $\mathrm{Bax}$ proteins in pre-B2 cells evaluated by flow cytometry. Impact of binding to stromal cells for $2 \mathrm{~h}$ with or without prior X-irradiation at $1 \mathrm{~Gy}$. Left side of figure: reactivity of cells with antibody by flow cytometry, vertical axis is median fluorescence channel. Right side of figure: ratio of Bcl-2 plus Bcl- ${ }_{\chi} \mathrm{L}$ over Bax. (C) Relative levels of Bcl-2 and Bcl- ${ }_{\chi \mathrm{L}}$ proteins evaluated by Western blot. Impact of binding to stromal cells for $2 \mathrm{~h}$. Note that levels of these two proteins in pre-B2 cells increases following binding to stroma and approach those observed with more primitive stroma-dependent pre-B1 cells. The results of one experiment are shown. Two other experiments produced essentially the same result

tic leukemia, involves a novel gene fusion product, BCR$\mathrm{ABL}$ kinase that effectively blocks the apoptotic response to $X$-irradiation and genotoxic damage (Bedi et al, 1995; Nishii et al, 1996).

\section{Materials and Methods}

\section{Suspension culture of pro-B, pre-B1, pre-B2 cells and mature $B$ cells}

Femoral bone marrow (BM) was obtained from $6-10$ week old BALB/ c mice. BM cells $\left(2 \times 10^{6}\right.$ cells $\left./ \mathrm{ml}\right)$ were cultured for 4 weeks at $37^{\circ} \mathrm{C}$ plus $7 \% \mathrm{CO}_{2}$ in RPMI 1640 medium supplemented with $10 \%$ FCS and $50 \mu \mathrm{M}$ 2-ME, as described by Whitlock and Witte, (1982). Cultures were fed weekly with an equal volume of fresh medium. After 4 weeks, non-adherent cells were incubated on petri dishes twice to remove adherent cells for $1 \mathrm{~h}$. Selective culture systems were then used to enumerate three sequential stages of early $B$ lineage development-pro-B, pre-B1 and pre-B2, as previously described (Faust et al, 1993; Hardy et al, 1991). Subsequent culture was as follows: for pro-B, non-adherent cells were cultured with the bone marrow stromal cell line, S17 (Collins and Dorshkind, 1987) for 2 weeks; for pre-B1, non-adherent cells were cultured with S-17 cells and IL7 $(50 \mathrm{U} / \mathrm{ml})$, and for pre-B2 cells, non-adherent cells were cultured with IL7 $(800 \mathrm{U} / \mathrm{ml})$ for 2 weeks. Then these non-adherent cells were used. Mature B cells from spleen were cultured with LPS (25 $\mu \mathrm{g} / \mathrm{ml}$; Difco Lab Inc, Detroit, MI) for 5 days and subsequently used for clonogenic assays, antibody staining and flow cytometry or Western blotting.

\section{Immunofluorescent staining}

Cells were analyzed for expression of cell surface determinants using monoclonal antibodies against c-kit (FITC anti-mouse; Pharmingen), B220 (PE anti-mouse; Pharmingen), BP-1, CD19, HSA, CD44
(KM201/anti-Pgp1, hybridoma cells from the American Type Culture Collection; IM7.8.1 antibody from Sigma Immunochemicals. Both antibodies are rat IgG1 anti-mouse CD44 reagents), FITC anti-mouse; Pharmingen), CD43 (FITC anti-mouse; Pharmingen), CD25a (FITC anti-mouse; Pharmingen), Thy-1 (anti-mouse; Sera-Lab, Sussex, UK) and Mac-1 (FITC anti-mouse; Pharmingen). For Bcl-2, Bcl- ${ }_{\chi}$ and $\mathrm{Bax}$ staining, the cells $\left(1 \times 10^{6}\right)$ were fixed in $70 \%$ ethanol/PBS, washed with $1 \%$ BSA/PBS three times and incubated with first antigen (Bcl-2; N-19; Santa Cruz Biotechnology Inc, California; or hamster antibody 3F11, Pharmingen, UK), (Bcl- ; M-125, Santa Cruz Biotechnology Inc, California, or a mouse monoclonal antibody $2 \mathrm{~A} 1$, a gift from $\operatorname{Dr} C \mathrm{~B}$ Thompson; (Ma et al, 1995)), Bax; rabbit antibody, a gift from $\mathrm{Dr} J$ Reed) for 30 min on ice. After washing with $1 \%$ BSA/PBS, cells were incubated with FITC-labelled goat anti-mouse immunoglobulin (Ig), FITC-labelled rabbit anti-hamster Ig or FITC-labelled goat anti-rabbit Ig (Southern Biotechnology Associates Inc) for $30 \mathrm{~min}$ on ice, and analyzed by FACScan (Becton Dickinson, California, USA).

\section{Analysis of apoptosis}

Cells were exposed to X-ray (0.5-4 Gy), dexamethasone (0.0001$1.0 \mathrm{uM})$, etoposide $(0.0001-1.0 \mathrm{ug} / \mathrm{ml})$ for up to $24 \mathrm{~h}$. The $X$-ray source (Pantak Ltd, Reading, UK) was set to $240 \mathrm{kV}$ and $10 \mathrm{~mA}$. The dose rate was $0.95-1.0 \mathrm{~Gy} / \mathrm{min}$. After culture, cells were fixed in $500 \mathrm{ul}$ of $70 \%$ ethanol $\left(-20^{\circ} \mathrm{C}\right)$ and resuspended in $1.0 \mathrm{ml}$ of phosphate-buffer saline containing propidium iodode $(40 \mathrm{ug} / \mathrm{ml})$ and RNAse $(100 \mathrm{ug} / \mathrm{ml})$. The cell suspension was incubated at $37^{\circ} \mathrm{C}$ for $30 \mathrm{~min}$ and cell cycle analysis was performed using FACScan, where the apoptotic cell fraction was detected in the red fluorescent sub- $G_{1}$ peak.

\section{Clonogenic assays}

Cell suspension from pro-B and pre-B1 cells were treated with several concentrations of drug or X-ray, and each $2 \times 10^{3}$ cells were plated on a semi-confluent layer of $X$-irradiated ( $30 \mathrm{~Gy}$ ) S-17 cells in 24 well flat- 
bottom plates with each medium. After 7 days, the colonies ( $>20$ cells) were counted. Suspensions of pre-B2 and mature B cells were $X$-irradiated and then $5 \times 10^{5}$ cells were plated in $0.3 \%$ agar with either IL7 $(800 \mathrm{U} / \mathrm{ml})$-for pre-B2, or LPS $(25 \mathrm{ug} / \mathrm{ml})-$ for mature B cells. Clonogenic survival was measured after 7 days. Pre-B2 and mature $B$ cells were similarly cultured in the continuous presence of varying concentrations of drugs (etoposide/VP-16 and dexamethasone).

\section{Analysis of X-ray survival data}

Each set of X-ray survival data was fitted by the method of maximum likelihood to a linear-quadratic exponential survival curve $(S=\exp -(\alpha D$ $\left.+\beta D^{2}\right)$ ), on the assumption of a Poisson distribution of surviving colonies between replicate plates. In all but two cases (Exp. 1 Spleen $B$ and Exp. 3 MT $(5 \mathrm{~h})$ ) there was no significant evidence of deviation from linearity (i.e., $\beta \neq 0$ ), so linear exponential fits were also made. Using the linear-quadratic fits throughout as the more conservative option, in each experiment the survival curves were compared to one another, ranked in order of increasing radiosensitivity and tested for significance of difference. Doses for $37 \%$ survival $\left(D_{37}\right)$ were calculated in each case.

\section{Cultures with matrigel}

Pre-B2 cells were cultured with Matrigel (growth factor reduced matrigel matrix, Becton Dickinson Labware, MA) plus IL7 with or without hyaluronic acid ( $100 \mu \mathrm{g} / \mathrm{ml}$; Sigma) in 24 well plates for 5 days. The cells were removed from Matrigel and irradiated ( $0-2 \mathrm{~Gy})$ and cultured in $0.3 \%$ agar for 7 days with IL7 $(800 \mathrm{U} / \mathrm{ml})$. Alternatively, after being cultured for 5 days, cells were irradiated $(0-2$ Gy) whilst still in contact with matrigel and cultured for a further $5 \mathrm{~h}$. The cells were then removed from matrigel and cultured in agar for 7 days with IL7 (800 U/ $\mathrm{ml}$ ). Colonies ( $>20$ cells) were enumerated and clonogenic survival calculated.

\section{Expression of the apoptosis regulating proteins}

Total cell lysates were prepared as described previously (Nishii et al, 1996). For each sample, $1 \times 10^{6}$ cells were lysed in buffer containing $0.5 \%$ Triton $\mathrm{X} 100$ and protease inhibitors. Protein samples where then subjected to $15 \%$ SDS - PAGE, transferred to Immobilon-P membrane (Millipore) and probed with anti-mouse $\mathrm{Bcl}-2$ or $\mathrm{Bcl}_{-}$, antibody (as above). Appropriate second antibodies conjugated with horseradish peroxidase were used and immune complexes were developed by ECL solution (Amersham). Parity of protein loading was checked by prior staining of membranes with the reversible protein detection kit (Sigma).

\section{Acknowledgements}

This work was supported by the UKCCCR Radiation Programme (MG, DTG), the Parker Hughes Foundation (DG), the Leukaemia Research Fund (IT, MG), the Japanese Foundation for Ageing and Health (KN) and the MRC (DP, DTG). We thank Ms Barbara Deverson for help with the manuscript.

\section{References}

Anderson RE and Warner NL (1976) lonizing radiation and the immune response. Adv. Immunol. 24: 215
Barres BA, Hart IK, Coles HSR, Burne JF, Voyvodic JT, Richardson WD and Raff MC (1992) Cell death and control of cell survival in the oligodendrocyte lineage. Cell 70: $31-46$

Bedi A, Barber JP, Bedi GC, El-Deiry WS, Sidransky D, Vala MS, Akhtar AJ, Hilton J and Jones RJ (1995) BCR-ABL-mediated inhibition of apoptosis with delay of G2/ $M$ transition afterDNA damage: a mechanism of resistance to multiple anticancer agents. Blood 86: 1148-1158

Billips LG, Petitte D, Dorshkind K, Narayanan R, Chiu C-P and Landreth KS (1992) Differential roles of stromal cells, interleukin-7, and kit-ligand in the regulation of B lymphopoiesis. Blood 79: 1185-1192

Blanco-Rodríguez J and Martínez-García C (1996) Spontaneous germ cell death in the testis of the adult rat takes the form of apoptosis: re-evaluation of cell types that exhibit the ability to die during spermatogenesis. Cell Prolif. 29: 13-31

Boise LH, González-García M, Postema CE, Ding L, Lindsten T, Turka LA, Mao X, Nuñez $\mathrm{G}$ and Thompson CB (1993) bcl-x, a bcl-2-related gene that functions as a dominant regulator of apoptotic cell death. Cell 74:597-608

Boise LH and Thompson CB (1996) Hierarchical control of lymphocyte survival. Science 274: $67-68$

Bowen ID and Lockshin RA (1981) Cell death in biology and pathology (London: Chapman and Hall)

Collins LS and Dorshkind K (1987) A stromal cell line from myeloid long-term bone marrow cultures can support myelopoiesis and B lymphopoiesis. J. Immunol. 138: $1082-1087$

Cory S (1995) Regulation of lymphocyte survival by the BCL-2 gene family. Annu. Rev. Immunol. 13: 513-543

Donehower LA and Bradley A (1993) The tumor suppressor p53. Biochim Biophys Acta 1155: 181-205

Ehlich A, Martin V, Müller W and Rajewsky K (1994) Analysis of the B-cell progenitor compartment at the level of single cells. Curr. Biol. 4: 573-583

Ellis RE, Yuan J and Horvitz HR (1991) Mechanisms and function of cell death. Annu. Rev. Cell Biol. 7: 663-698

FaustEA, Saffran DC, Toksoz D, Williams DA and Witte ON (1993) Distinctive growth requirements and gene expression patterns distinguish progenitor $B$ cells from pre-B cells. J. Exp. Med. 177: 915-923

Fuks Z, Vlodavsky I, Andreeff M, McLoughlin M and Haimovitz-Friedman A (1992) Effects of extracellular matrix on the response of endothelial cells to radiation in vitro. Eur. J. Cancer 28A: 725-731

Gajewski TF and Thompson CB (1996) Apoptosis meets signal transduction: elimination of a BAD influence. Cell 87: $589-592$

Gibson LF, Piktel D, Narayanan R, Nuñez G and Landreth KS (1996) Stromal cells regulate $b c l-2$ and bax expression in pro-B cells. Exp. Hematol. 24: 628-637

Gordon MY, Riley GP, Watt SM and Greaves MF (1987) Compartmentalization of a haematopoietic growth factor (GM-CSF) by glycosaminoglycans in the bone marrow microenvironment. Nature 326: 403-405

Gratiot-Deans J, Merino R, Nuñez G and Turka LA (1994) Bcl-2 expression during Tcell development: early loss and late return occur at specific stages of commitment to differentiation and survival. Proc. Natl. Acad. Sci. USA 91: $10685-10689$

Greaves MF (1993) Stem cell origins of leukaemia and curability. Br. J. Cancer 67: $413-423$

Griffiths SD, Clarke AR, Healy LE, Ross G, Ford AM, Hooper ML, Wyllie AH and Greaves M (1997) Absence of $p 53$ permits propagation of mutant cells following genotoxic damage. Oncogene 14:523-531

Griffiths SD, Goodhead DT, Marsden SJ, Wright EG, Krajewski S, Reed JC, Korsmeyer SJ and Greaves M (1994a) Interleukin 7-dependent B lymphocyte precursor cells are ultrasensitive to apoptosis. J. Exp. Med. 179: 1789-1797

Griffiths SD, Marsden SJ, Wright EG, Greaves MF and Goodhead DT (1994b) Lethality and mutagenesis of B lymphocyte progenitor cells following exposure to $\alpha$-particles and X-rays. Int. J. Radiat. Biol. 66: 197-205

Grillot DAM, Merino R and Nuñez (1995) Bcl-xL displays restricted distribution during Tcell development and inhibits multiple forms of apoptosis but not clonal deletion in transgenic mice. J. Exp. Med. 182: 1973-1983

Grillot DAM, Merino R, Pena JC, Fanslow WC, Finkelman FD, Thompson CB and Nuñez $G$ (1996) bcl-x exhibits regulated expression during B cell development and activation and modulates lymphocyte survival in transgenic mice. J. Exp. Med. 183: 381-391

Haldar S, Jena Nand Croce CM (1995) Inactivation of Bcl-2 by phosphorylation. Proc. Natl. Acad. Sci. USA 92: 4507-4511 
Hardy RR, E CC, Shinton SA, Kemp JD and Hayakawa K (1991) Resolution and characterization of pro-B and pre-pro-B cell stages in normal mouse bone marrow. J. Exp. Med. 173: 1213-1225

Hayashi S-I, Kunisada T, Ogawa M, Sudo T, Kodama H, Suda T, Nishikawa S and Nishikawa S-I (1990) Stepwise progression of B lineage differentiation supported by interleukin 7 and other stromal cell molecules. J. Exp. Med. 171: 1683-1695

Judas L, Bentzen SM, Hansen PV and Overgaard J (1996) Proliferative response of mouse spermatogonial stem cells after irradiation: a quantitative model analysis of experimental data. Cell Prolif. 29: 73-87

Kee BL and Paige CJ (1995) Murine B cell development: commitment and progression from multipotential progenitors to mature B lymphocytes. Int. Rev. Cytol. 157: 129-179

Kincade PW (1987) Experimental models for understanding B lymphocyte formation. Adv. Immunol. 41: 181-267

Kitada S, Krajewski S, Miyashita T, Krajewska M and Reed JC (1996) $\gamma$-Radiation induces upregulation of Bax protein and apoptosis in radiosensitive cells in vivo. Oncogene 12: 187-192

Komarova EA, Chernov MV, Franks R, Wang K, Armin G, Zelnick CR, Chin DM, Bacus SS, Stark GR and Gudkov AV (1997) Transgenic mice with p53responsive lacZ: p53 activity varies dramatically during normal development and determines radiation and drug sensitivity in vivo. EMBO J. 16: 1391-1400

Kuerbitz SJ, Plunkett BS, Walsh WV and Kastan MB (1992) Wild-type p53 is a cel cycle checkpoint determinant following irradiation. Proc. Natl. Acad. Sci. USA 89: $7491-7495$

Lesley J, He Q, Miyake K, Hamann A, Hyman R and Kincade PW (1992) Requirements for hyaluronic acid binding by CD44: a role for the cytoplasmic domain and activation by antibody. J. Exp. Med. 175: 257-266

Linette GP, LiY, Roth K and Korsmeyer SJ (1996) Cross talk between cell death and cell cycle progression: BCL-2 regulates NFAT-mediated activation. Proc. Natl. Acad. Sci. USA 93: 9545-9552

Liu Y-J, Mason DY, Johnson GD, Abbot S, Gregory CD, Hardie DL, Gordon J and MacLennan ICM (1991) Germinal center cells express bcl-2 protein after activation by signals which prevent their entry into apoptosis. Eur. J. Immunol. 21: 1905-1910

Ma A, Pena JC, Chang B, Margosian E, Davidson L, AltFW and Thompson CB (1995) Bclx regulates the survival of double-positive thymocytes. Proc. Natl. Acad. Sci. USA 92: $4763-4767$

Manabe A, Coustan-Smith E, Behm FG, Raimondi SC and Campana D (1992) Bone marrow-derived stromal cells prevent apoptotic cell death in B-lineage acute lymphoblastic leukemia. Blood 79: 2370-2377

Matsuzaki Y, Nakayami K-i, Nakayama K, Tomita T, Isoda M, Loh DY and Nakauchi H (1997) Role of bcl-2 in the development of lymphoid cells from the hematopoietic stem cell. Blood 89: 853-862

MazelS, Burtrum D and Petrie HT (1996) Regulation of cell division cycle progression by $b c l-2$ expression: a potential mechanism for inhibition of programmed cell death. J. Exp. Med. 183: 2219-2226

Merino R, Ding L, Veis DJ, Korsmeyer SJ and Nuñez G (1994) Developmental regulation of the $\mathrm{Bcl}-2$ protein and susceptibility to cell death in $\mathrm{B}$ lymphocytes. EMBO J. 13: 683-691

Miyake K, Medina KL, Hayashi S-I, Ono S, Hamaoka T and Kincade PW (1990) Monoclonal antibodies to Pgp-1/CD44 block lympho-hemopoiesis in long-term bone marrow cultures. J. Exp. Med. 171: 477-488

Miyashita T, Krajewski S, Krajewska M, Wang HG, Lin HK, Liebermann DA, Hoffman $B$ and Reed JC (1994) Tumor suppressor 533 is a regulator of $b c l$-2and baxgene expression in vitro and in vivo. Oncogene 9: 1799-1805

MuellerDL, Seiffert S, Fang W and Behrens TW (1996) Differential regulation of $b c l-2$ and $b c l-x$ by CD3, CD28, and IL-2 receptor in cloned CD4 ${ }^{+}$helper T cells. J. Immunol. 156: 1764-1771
Nicholson DW, Ali A, Thornberry NA, Vaillancourt JP, Ding CK, Gallant M, Gareau Y, Griffin PR, Labelle M, Lazebnik YA, Munday NA, Raju SM, Smulson ME, Yamin TT, Yu VL and Miller DK (1995) Identification and inhibition of the ICE/CED-3 protease necessary for mammalian apoptosis. Nature 376: $37-43$

Nishii K, Kabarowski JHS, Gibbons DL, Griffiths SD, Titley I, Wiedemann LM and Greaves MF (1996) ts BCR-ABL kinase activation confers increased resistance to genotoxic damage via cell cycle block. Oncogene 13: 2225-2234

Norimura T, Nomoto S, Katsuki M, Gondo Y and Kondo S (1996) p53-dependent apoptosis suppresses radiation-induced teratogenesis. Nat. Med. 2: $577-580$

Nuñez G, Merino R, Grillot D and González-García M (1994) Bcl-2 and Bcl-x: regulatory switches for lymphoid death and survival. Immunol. Today 15: 582588

O'Reilly LA, Huang DCS and Strasser A (1996) The cell death inhibitor Bcl-2 and its homologues influence control of cell cycle entry. EMBO J. 15: 6979-6990

Osmond DG, Rico-Vargas S, Valenzona H, Fauteux L, Liu L, Janani R, Lu L and Jacobsen K (1994) Apoptosis and macrophage-mediated cell deletion in the regulation of B lymphopoiesis in mouse bone marrow. Immunol. Rev. 142:209230

Rabbitts TH(1994)Chromosomal translocations in human cancer. Nature 372:143149

Raff MC (1996) Size control: the regulation of cell numbers in animal development. Cell 86: $173-175$

Rolink A and Melchers F (1991) Molecular and cellular origins of B lymphocyte diversity. Cell 66: 1081-1094

Rolink A, Streb M, Mishikawa S-I and Melchers F (1991) The c-kit-encoded tyrosine kinase regulates the proliferation of early pre-B cells. Eur. J. Immunol. 21:26092612

Ruoslahti E and Reed JC (1994) Anchorage dependence, integrins, and apoptosis. Cell $77: 477-478$

Sato T, Hanada M, Bodrug S, Irie S, Iwama N, Boise LH, Thompson CB, Golemis E Fong L, Wang H-G and Reed JC (1994) Interactions among members of the Bcl-2 protein family analyzed with a yeast two-hybrid system. Proc. Natl. Acad. Sci. USA 91: $9238-9242$

Sellins KS and Cohen JJ (1987) Gene induction by $\gamma$-irradiation leads to DNA fragmentation in lymphocytes. J. Immunol. 139: 3199-3206

Strasser A, Harris AW, Jacks T and Cory S (1994) DNA damage can induce apoptosis in proliferating lymphoid cells via p53-independent mechanisms inhibitable by Bcl-2. Cell 79: 329-339

Trowell OA (1952) The sensitivity of lymphocytes to ionizing radiation. J. Pathol. Bacteriol. 64: 687-704

Vaux DL and Strasser A (1996) The molecular biology of apoptosis. Proc. Natl. Acad. Sci. USA 93: 2239-2244

Veis DJ, Sentman CL, Bach EA and Korsmeyer SJ (1993) Expression of the Bcl-2 protein in murine and human thymocytes and in peripheral T lymphocytes. J. Immunol. 151: 2546-2554

Ward JF (1988) DNA damage produced by ionizing radiation in mammalian cells: identities, mechanisms of formation and repairability. Prog. Nucleic Acid Res. Mol. Biol. 35: 95-125

Whitlock CA and Witte ON (1982) Long-term culture of B lymphocytes and their precursors from murine bone marrow. Proc. Natl. Acad. Sci. USA 79:3608-3612

Williams GT, Smith CA, McCarthy NJ and Grimes EA (1992) Apoptosis: final contro point in cell biology. Trends Cell Biol. 2: 263-267

Yang E and Korsmeyer SJ (1996) Molecular thanatopsis: a discourse on the BCL2 family and cell death. Blood 88: 386-401 